A rotary chart translator enables a large number of circular charts to be re-recorded on a single strip chart with a reduced time base to facilitate a detailed study of blast-furnace blowing requirements. A 48-way rocorder enables temperatures at different points in ingot moulds after teoming to be studied.

\section{TECHNICAL BOOKS AND INFORMATION}

$\mathrm{T}$

HE Senttish Branch of Aslib held a conference in the Mitchell Library, Glasgow, on October 6. The conference was opened by Mr. C. A. Oakley, who spoke on this occasion as the author of several technical books, and not in his official capacity as reginnal controller for Sentland of the Board of Trade. He regretted that Glasgow has a reputation as a 'tough' city, largely due to certain bonks written about it, and said that he had written "The Second City" in answer. Mr. Oakley went on to suggest that this unsavoury reputation is a factor in the problem of bringing new industries to Scotland. There is no difficulty in persuading managers to come and live in the Glasgow area; but the charge-hand type of worker has taken his idea of the city from news and bonks. Describing his own experience, Mr. Oakley said that too froquently an author of technical books has to meet the cost of publication, and it is rare that this type of book produces substantial royalties. It may take ten years to collect the material, and technical books are better if they are written slowly over a period of years rather than tackled and finished in a fow months.

Mr. James Fergusson, Keeper of the Records of Scotland, outlined the history and care of the records of Scotland and stressed that the live, active interest of the people is necessary to solve the problems facing Register House.

Sir James French, speaking on "Books in Industry", said that books should be available for self-education, and advocated numerous well-distributed collections of technical works. Ho suggested that money for this would be well spent, and could well be seved by reducing the school-leaving age to thirteen. His experience over many years has proved that youths at thirteen are ready and willing to leave school, and gain more from an earlier apprenticeship to a trade than from an enforced attendance at school, which bores them and wastes their time. Sir James said that even the most modern books are in some degree historical and that "pioneers of industry spend their lives hunting in unknown forests for which there are no guide books, until they themselves may write them".

The next speaker, Mr. W. A. Beck, superintendent for Scotland of H.M. Stationery Office, outlined the publications available and described the various classes of papers published. The last paper, by MIr. S. Weinberg, resoarch manager of Messrs. G. and $J$. Weir, Ltd., was on "The Attitude of the Research Worker to Technical Information". He quoted Sir Alfred Egerton, giving the present rate of publication of scientific papers as approxinately one million, ninety per cent of which are only written to publicize their author's existence. There is no easy solution, because a publication giving arbitrary results might well have a value in the experimental techniques described. Too often the librarian regards the research worker as an individual pursuing a certain line of inquiry for a particular project. Ninety per cent of his reading time must be allocated for routine 'keeping abreast', but reading time for a specialized job cannot be arbitrarily decided. Mr. Weinberg said that it is useless for the research worker to attempt to examine more than one-tenth of one per cent of published material, which works out at twenty to twenty-five papers or articles a week. Of these, onetenth may be of immediate interest, and a fraction of wider interest. In this connexion, it was stressed that editors cannot pay too much attention to the 'contents' page. Selection of material should always be the responsibility of the research worker and should not be left to the librarian, although the latter can usefully do the routine work of abstracting after the initial selection. From experience, Mr. Weinberg regretted that the emphasis in abstracts is on results, which are often of less use than the operational techniques and the experimental results prior to analysis.

Mr. Weinberg put forward a plea for discrimination on the part of editors and secretaries of learned societies, and he hoped that the advantages of personal publicity would be reduced in such a manner as to discourage all but the better papers. Repetition should either be avoided or clearly indicated. Until it is possible to dial the number of the information required and see it flashed on a screen, the bringing together of the librarian and research worker on a personal basis is most likely at this stage to produce beneficial results.

\section{MILK RECORDING AND BREEDING OF DAIRY CATTLE}

SINCE most of the important statutory activities D of the Milk Marketing Board were taken over by the Ministry of Food at the beginning of the Second World War, and have not yet been restored to it, a good deal of the energies and the not inconsiderable financial resources of the Board have been of recent years devoted to the milk recording and breeding movement, with the ultimate objective of improving milk yields per cow and also milk quality. Dr. Joseph Edwards, head of the Production Division of the Milk Marketing Board, in an address to the Farmers' Club at a meeting in London on October 2 , gave a valuable account of the extensive progress made in three fields : milk recording (National Milk Records) since the Milk Marketing Board took over this scheme from the Ministry of Agriculture in 1943 ; the development since 1947 of the Milk Marketing Board Bureau of Records; and artificial insemination of dairy cows which, following the pioneer work started in 1942 at the experimental centres at Cambridge and Reading, was taken up on a commercial scale by the Board in 1945.

In the first of these fields, the number of recorded herds has gone up from just over 4,000 to more than 24,000 ; about twenty per cent of the dairy cows in England and Wales are now recorded for yield. Some progress has also been made in recording butterfat percentage; about seven per cent of dairy cows are now in the scheme. All recorded cows are identified by ear-marking, itself no inconsiderable task. As regards development since 1947 of the Bureau of Records, this Bureau publishes annually a report and analysis of the figures obtained from the National Milk Records, a publication of real value to most of 